\title{
Antitumor and antiangiogenic activity of soy isoflavone genistein in mouse models of melanoma and breast cancer
}

\author{
HERNÁN G. FARINA, MONICA POMIES, DANIEL F. ALONSO and DANIEL E. GOMEZ \\ Laboratory of Molecular Oncology, Department of Science and Technology, \\ Quilmes National University, Buenos Aires, Argentina
}

Received March 20, 2006; Accepted May 19, 2006

\begin{abstract}
Tumor invasion, angiogenesis and metastasis involve secretion of proteolytic enzymes and cell migration into blood vessels. Tumor cells are capable of degrading the extracellular matrix via a proteolytic cascade that includes urokinase-type plasminogen activator (uPA) and matrix metalloproteases (MMPs). We have investigated the antitumor and antiangiogenic properties of soy isoflavone genistein in B16 melanoma and F3II mammary carcinoma mouse models. At non-cytotoxic concentrations $(0.1-50 \mu \mathrm{M})$ genistein induced dosedependent spindle-cell morphology and significantly reduced motility in both cell lines. Genistein inhibited uPA secreted by F3II cell monolayers, while inducing an increase in the proteolytic activity of B16 cells. On the contrary, the compound did not modify the MMP-9 and -2 produced by tumor cells. In vivo, i.p. administration of genistein at a dose of $10 \mathrm{mg} / \mathrm{kg} /$ day reduced tumor-induced angiogenesis in syngeneic mice implanted with B16 or F3II cells. Similar antiangiogenic effects were obtained with a soybean-based diet. This data suggest that tumor cell migration and proteolysis may be associated with the antitumor and antiangiogenic activity of soy isoflavone genistein.
\end{abstract}

\section{Introduction}

Tumor angiogenesis plays a pivotal role in the complex, multistep nature of cancer growth and spread. Angiogenesis is intimately involved in metastasis at the site of entry of tumor cells into the vasculature, as well as at the site of eventual metastasis $(1,2)$. In this regard, a relationship between tumor cell invasion and tumor-induced angiogenesis was described, with cooperative functions of both processes during tissue breakdown and cell migration (3).

Correspondence to: Dr Hernán G. Farina, Laboratory of Molecular Oncology, Department of Science and Technology, Quilmes National University, R. Sáenz Peña 180, Bernal B1876BXD, Buenos Aires, Argentina

E-mail: hgfarina@unq.edu.ar

Key words: genistein, soybean diet, urokinase-type plasminogen activator, tumor invasion, angiogenesis
Degradation of tissue barriers during tumor invasion is associated with proteolytic activity, mediated by tumor cells and also the surrounding host cells (4-6). Cancer cells are capable of digesting the extracellular matrix (ECM) via a proteolytic cascade that includes the urokinase-type plasminogen activator (uPA) and the matrix metalloproteases (MMPs). uPA is a serine protease that activates plasmin, a broad-specificity protease which degrades ECM components such as fibronectin and laminin. In addition, uPA can trigger activation of MMPs, which are responsible for collagen degradation. Increased pericellular proteolysis facilitates cell migration, and may promote the release of angiogenic and growth factors from the ECM (5).

Genistein (4'5,7-trihydroxyisoflavone) occurs in the plant family Leguminosae, including soybean (Glycine max). Epidemiologic evidence suggests that soybean-based diets, and particularly genistein, may reduce the risk of tumor formation. Other evidence is based on the molecular and cellular mechanisms of action of genistein on both normal and cancer cells (7). Hewitt and Singletary have studied the effect of genistein alone or as a part of a commercial soy extract on the growth of the highly metastatic mouse mammary carcinoma model F3II (8). Genistein significantly inhibited F3II cell proliferation in vitro at micromolar concentrations, and caused G2/M arrest associated with increased expression of phosphorylated $\mathrm{p} 34$ and cyclin B1. In vivo, diets supplemented with either a soy extract or genistein induced a significant reduction of F3II subcutaneous tumors. Similarly, genistein blocked G1/S transition in B16 melanoma cells and induced the cyclin-dependent kinase-2 inhibitor p21 (9). The isoflavone also reduced subcutaneous growth of B16 tumors (10), and exerted antiangiogenic effects in combination with cyclophosphamide treatment in the same model (11).

In the present study, we have investigated the antitumor properties of genistein in F3II mammary carcinoma and B16 melanoma cell cultures, with particular interest in the effects on cell motility and protease secretion. In vivo, antitumor activity was explored using a tumor-induced angiogenesis assay in mice implanted with tumor cells and treated with genistein or fed with a soybean-based diet.

\section{Materials and methods}

Compound. Genistein was purchased from Sigma (St. Louis, $\mathrm{MO})$. For cell culture experiments, genistein was dissolved in dimethyl sulfoxide (DMSO) and then diluted into culture 
medium at a final concentration of $0.5 \%$ DMSO, a level which had no effect on tumor cells. For in vivo studies genistein was sonicated into suspension in $0.9 \%$ saline prior to injection. The dose administered in vivo was selected based upon previous preclinical and clinical studies $(12,13)$.

Tumor cells and culture conditions. We used the sarcomatoid mammary carcinoma cell line F3II, established from a clone of a spontaneous, hormone-independent Balb/c mouse mammary tumor (14) and the parental B16F0 melanoma cell line, syngeneic for the C57BL/6 mouse strain. Stock F3II and B16 cells were maintained in monolayer culture in minimal essential medium (MEM) and Dulbecco's modified Eagle's medium (DMEM) from Gibco (Grand Island, NY), respectively, supplemented with heat-inactivated $10 \%$ fetal bovine serum (FBS), $2 \mathrm{mM}$ glutamine and $80 \mu \mathrm{g} / \mathrm{ml}$ gentamicin. For harvesting, cells were trypsinized using standard procedures and incubated in serum-free culture medium for $1 \mathrm{~h}$ at $37^{\circ} \mathrm{C}$ for recovery. Quantification of cell number was made by hemacytometer counting. In all cases, viability was $>90 \%$, as assayed by trypan blue exclusion test.

In vitro growth and cytotoxicity assays. The effect of genistein on the in vitro growth of F3II and B16 cells was determined by colorimetric assay. Tumor cells suspensions were seeded on 96-well plates at a density of 200 cells/well in culture medium plus $5 \%$ FBS. After $24 \mathrm{~h}$, a range of concentrations from 0.5 to $100 \mu \mathrm{M}$ of genistein was added and incubation continued for $96 \mathrm{~h}$. Plates were fixed with $10 \%$ formalin, stained with toluidine blue and the cellular mass was estimated from the absorbance at $595 \mathrm{~nm}$. In addition, to assess the cytotoxicity of genistein against slowly-growing tumor cells, semi-confluent F3II and B16 monolayers were exposed to genistein for $24 \mathrm{~h}$. Cytotoxicity was evaluated using a commercial kit from Promega (Madison, WI).

Tumor cell morphology. To examine the effects of genistein on cell morphology, F3II and B16 monolayers were cultured in 6-well plates for $24 \mathrm{~h}$ in the presence of genistein and photographed in a phase contrast microscope at x200 magnification (Olympus, Tokyo, Japan).

Adhesion assay. Semi-confluent F3II and B16 monolayers were cultured for $24 \mathrm{~h}$ in the presence or absence of genistein. Control and pretreated tumor cell suspensions were prepared from these monolayers and seeded at $4 \times 10^{4}$ cells/well in culture medium plus 5\% FBS on wells precoated with the ECM protein fibronectin $\left(2 \mu \mathrm{g} / \mathrm{cm}^{2}\right)$. After 60 -min incubation at $37^{\circ} \mathrm{C}$, wells were washed with PBS and adherent cells were fixed with methanol, stained with crystal violet, solubilized in acetic acid-methanol (10-5\%) and quantified at $595 \mathrm{~nm}$.

Migration assay. Tumor cell migration was measured by an in vitro wound assay (15). Confluent F3II and B16 monolayers were wounded by scratching $0.5-\mathrm{mm}$ lines with a plastic tip. After washing with PBS, tumor cells were incubated for $15 \mathrm{~h}$ in culture medium containing $10 \%$ FBS, with or without genistein, to allow the cells to migrate into the wound. Monolayers were fixed, stained with methylene blue and the number of cells that had advanced into the cell-free space was counted with a $0.36-\mathrm{mm}^{2}$ reticule at $\times 100$ magnification.
Preparation of conditioned media. Secreted tumor-derived proteases were investigated in conditioned media, as previously described (16). Semi-confluent F3II and B16F0 monolayers were extensively washed in PBS to eliminate serum traces and incubated in serum-free culture medium for $24 \mathrm{~h}$ with the appropriate concentrations of genistein. Samples were individually harvested and stored at $-20^{\circ} \mathrm{C}$ until assayed. The remaining monolayers were used to estimate the cell number.

Casein zymography and radial caseinolytic assay. SDS-polyacrylamide gels were performed using $4 \%$ stacking and $7.5 \%$ separating gels. The separating gel was copolymerized with $12 \mu \mathrm{g} / \mathrm{ml}$ purified plasminogen (Chromogenix, Mölndal, Sweden) and $5 \mathrm{mg} / \mathrm{ml}$ non-fat dried milk as casein source. After electrophoresis, gels were washed with $2 \%$ Triton X-100 and incubated at $37^{\circ} \mathrm{C}$ for $72 \mathrm{~h}$ in $20 \mathrm{mM}$ Tris buffer ( $\mathrm{pH} 8.3$ ) containing $15 \mathrm{mM}$ EDTA. Upon staining with Coomassie blue and distaining, the final gel had a uniform blue background except in those regions to which plasminogen activators had migrated and activated plasmin degradation. Molecular weights were determined by pre-stained standards (Bio-Rad, Hercules, CA). Plasminogen-free gels were used to test plasminogenindependent protease activity. A complementary radial caseinolytic assay using plasminogen-rich casein-agarose plates was employed to quantify uPA and tissue-type plasminogen activator (tPA) activities contained in conditioned media, as described (17). To assess tPA-dependent activity, amiloride was added to the substrate at a concentration of $0.2 \mathrm{mM}$. This drug selectively blocks uPA activity, having no inhibitory activity against tPA or plasmin (18).

Gelatin zymography. MMP activity secreted by F3II and B16F0 cells was determined in SDS-polyacrylamide gels copolymerized with gelatin $(1 \mathrm{mg} / \mathrm{ml})$, using $4 \%$ stacking and $7.5 \%$ separating gels. After washing, gels were incubated at $37^{\circ} \mathrm{C}$ for $72 \mathrm{~h}$ in $0.2 \mathrm{M} \mathrm{NaCl}, 5 \mathrm{mM} \mathrm{CaCl}_{2}$ and $50 \mathrm{mM}$ Tris- $\mathrm{HCl}$ buffer ( $\mathrm{pH}$ 7.4) for MMP detection or in the same buffer containing $15 \mathrm{mM}$ EDTA to detect metal-independent protease activity. Gels were stained with Coomassie blue, and gelatinolytic enzymes were detected as gelatin degraded bands in a dark background.

Preparation of soybean-based diet. We used soy grains from the 'Don Mario' 4800RR variety. An amount of $500 \mathrm{~g}$ of grains was soaked overnight with $1350 \mathrm{ml}$ of tap water to obtain a paste by liquefaction. The paste was microwaved for $1 \mathrm{~min}$ to inactivate trypsin inhibitors, manipulated to generate a soybean-based rodent chow and then dried at $40^{\circ} \mathrm{C}$ for $48 \mathrm{~h}$. A standard rodent chow with regular fat content was used as a control.

In vivo assays. Specific pathogen-free female Balb/c and C57BL/6 inbred mice from UNLP (Buenos Aires, Argentina), with an age of 6-8 weeks and an average weight of 20-25 g, were used. They were housed in plastic cages under standard conditions and had access to rodent chow and water ad libitum. On the designated day 0 of the experiment, F3II or B16F0 cells, at concentrations of $2 \times 10^{5}$ or $1 \times 10^{5}$ viable cells, respectively, were injected intradermally in the flanks of unanesthetized mice. At day 5, animals were sacrificed after anesthesia with sulfuric ether. The sites of tumor implantation were photo- 
A

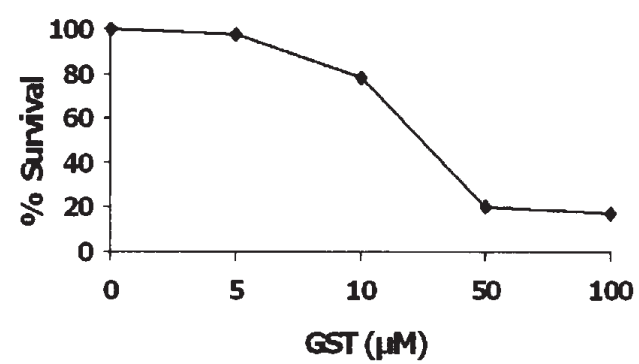

B

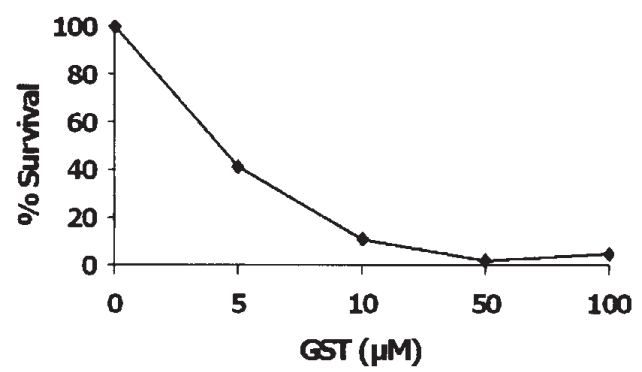

Figure 1. Effect of genistein on the growth of (A) F3II mammary tumor cells and (B) B16F0 melanoma cells. Survival relative to untreated control cells was determined by a colorimetric assay after incubation for $96 \mathrm{~h}$ with genistein $(0.5-100 \mu \mathrm{M})$. Results are representative of three independent experiments. In all cases, standard errors of means average $<10 \%$. graphed and the vascularization was quantified as reported previously (19). To study the effect of genistein on tumor implants mice were injected i.p. at daily doses of $15 \mathrm{mg} / \mathrm{kg}$ body weight from days 1-5 or received a soybean-based diet. Animals were monitored for food and water consumption, weight, and general behavioral status.

\section{Results}

Effects of genistein on in vitro growth. The IC50 value for genistein, evaluated by a 96-h exposure to the compound, was 26.3 and $6.6 \mu \mathrm{M}$ for F3II and B16F0 cells, respectively (Fig. 1). However, genistein had no cytotoxic effects when tumor cells were treated at a dose of up to $100 \mu \mathrm{M}$ for $24 \mathrm{~h}$ followed by incubation for 3 days without the compound, as indicated by approximately $90 \%$ survival at these doses (data not shown). Similarly, this range of concentrations (1-100 $\mu \mathrm{M}$ ) had no cytotoxic effects when assayed for $24 \mathrm{~h}$ on semiconfluent, slowly-growing F3II and B16F0 monolayers. Since further in vitro experiments were all performed treating tumor cells for up to $24 \mathrm{~h}$, these concentrations of genistein were employed to achieve maximum levels of drug action consistent with an absence of cytotoxicity.

Effects of genistein on tumor cell morphology, adhesion and motility. At non-cytotoxic concentrations, genistein induced a
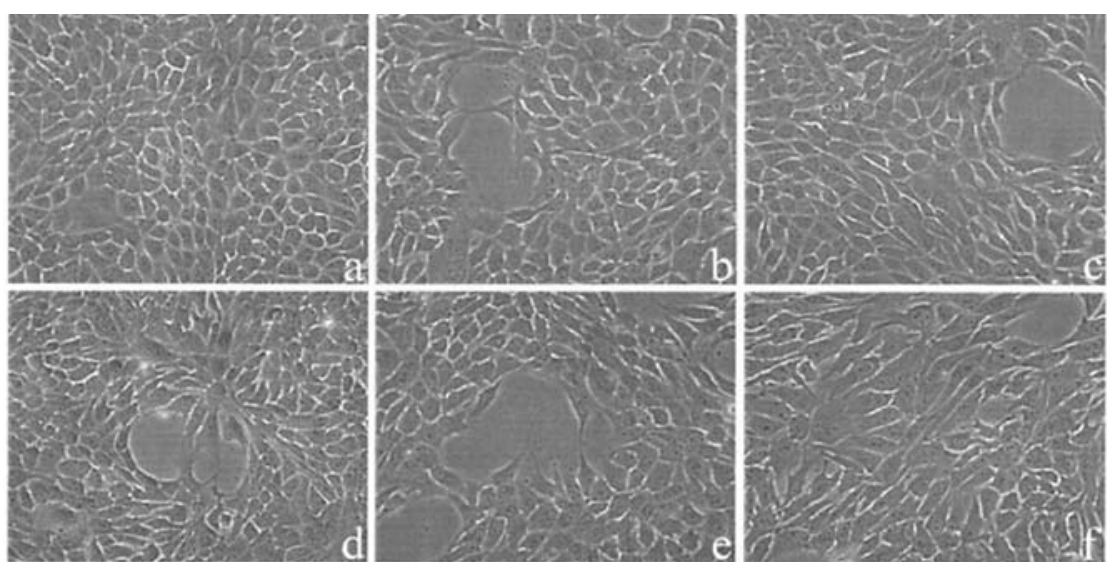

F3II
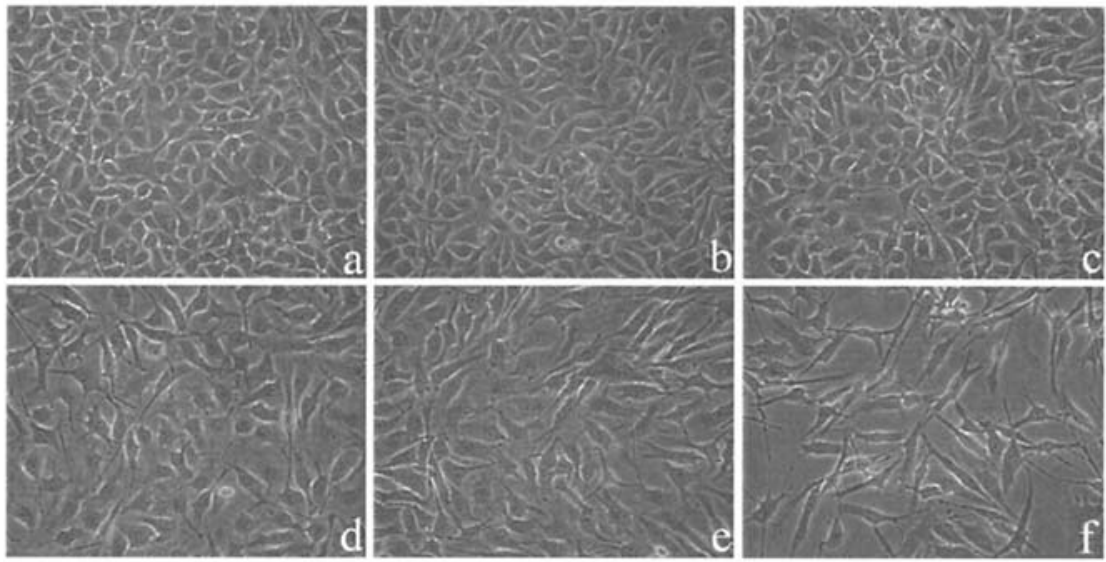

\section{B16F0}

Figure 2. Effect of genistein on F3II and B16F0 tumor cell morphology. Monolayers were cultured for $24 \mathrm{~h}$ with or without genistein and photographed in a phase contrast microscope at $\mathrm{x} 200$ magnification. (a) Control, (b) $0.5 \mu \mathrm{M}$ genistein, (c) $1 \mu \mathrm{M}$ genistein, (d) $10 \mu \mathrm{M}$ genistein, (e) $20 \mu \mathrm{M}$ genistein, (f) $50 \mu \mathrm{M}$ genistein. 
A

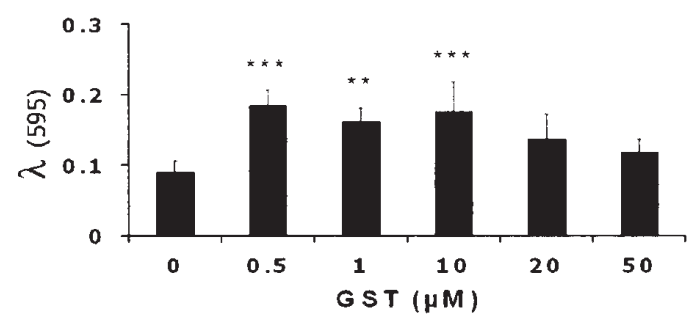

B

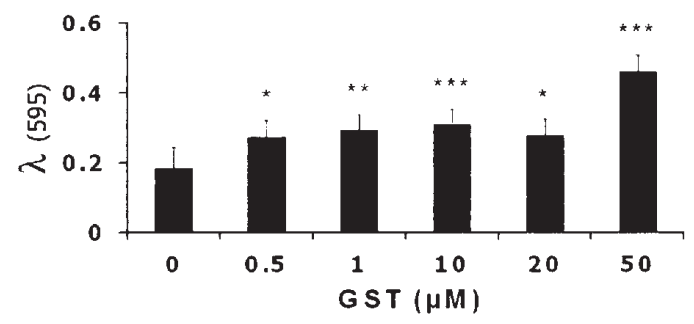

Figure 3. Effect of genistein on F3II and B16F0 cell adhesion. Tumor cells were pretreated in monolayer culture with different doses of genistein for $24 \mathrm{~h}$, harvested and seeded on wells precoated with fibronectin $\left(2 \mu \mathrm{g} / \mathrm{cm}^{2}\right)$ in the presence of serum. GST, genistein. Data are expressed as mean \pm SD of triplicate determinations, and are representative of three independent experiments. ${ }^{*} \mathrm{p}<0.05,{ }^{* *} \mathrm{p}<0.01,{ }^{* * *} \mathrm{p}<0.001$ versus control (ANOVA test).

dose-dependent spindle-cell morphology on both cell lines (Fig. 2). The adhesion rate of F3II and B16F0 cells to uncoated plastic surfaces was time-dependent and the plateau was reached after 30-60 min. Similar results were obtained using wells precoated with fibronectin. Pretreatment with genistein at concentrations from 0.5 to $50 \mu \mathrm{M}$ increased the adhesion of F3II and B16F0 tumor cells (Fig. 3). However, the presence of genistein during the adhesion assay, but without pretreatment of tumor cells, did not reduce tumor cell attachment (data not shown). Genistein significantly reduced tumor cell migration, in doses from 1 to $50 \mu \mathrm{M}$ for F3II cells and from 20 to $50 \mu \mathrm{M}$ for B16F0 cells (Fig. 4).

Effects of genistein on tumor-derived proteolytic activity. Zymographic analysis of plasminogen activators contained in conditioned media revealed a main band of $45 \mathrm{kDa}$ and a less prominent band of $67 \mathrm{kDa}$. These forms were identified as uPA and $\mathrm{PPA}$, respectively, by preincubation with anti-catalytic antibodies and Western blotting, as reported previously (19). Genistein was able to disrupt the secretion of plasminogen activators by F3II and B16 cells. Genistein decreased uPA secreted by F3II cells in doses ranging between 10 and $50 \mu \mathrm{M}$ (Fig. 5A). Likewise at $0.5-1 \mu \mathrm{M}$ the drug increased tPA, an enzyme related with good prognosis in mammary tumors. On the contrary, genistein induced an increase on uPA and tPA secretion in B16 cells (Fig. 5B). These results were confirmed using a radial caseinolytic assay (data not shown). F3II and B16F0 cultures secreted a main metalloproteinase activity of $105 \mathrm{kDa}$ and a minor band of $70 \mathrm{kDa}$, corresponding to MMP-9 and -2, respectively. Genistein did not modify this gelatinolytic pattern (data not shown).

In vivo effects of genistein and soybean-based diet on tumorinduced angiogenesis. Since adhesion, proteolysis and
A

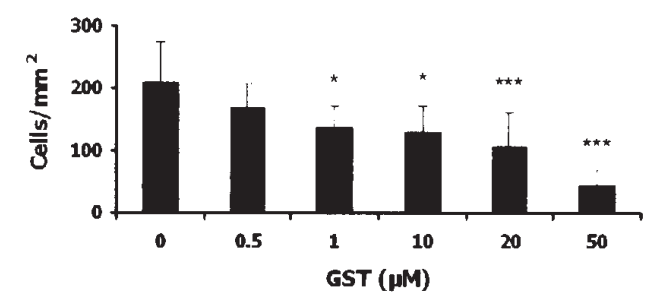

B

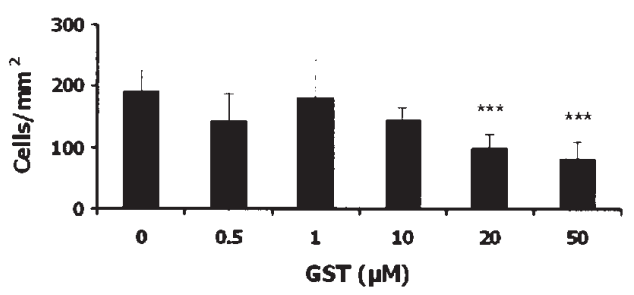

Figure 4. Effects of genistein on F3II and B16F10 cell migration. The in vitro wound assay was performed as described in Materials and methods. (A) F3II, (B) B16F0 cells. GST, genistein. Value represents means \pm SD of at least 12 determinations from three separate experiments. ${ }^{*} \mathrm{p}<0.05,{ }^{* *} \mathrm{p}<0.01,{ }^{* * * *} \mathrm{p}<0.001$ versus control (ANOVA test).

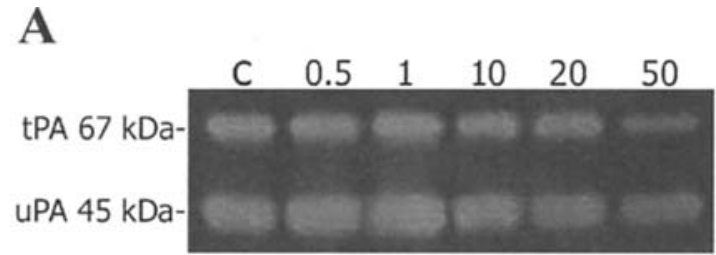

B

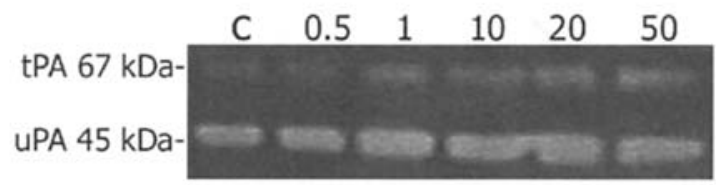

Figure 5. Zymographic analysis of plasminogen activators secreted by tumor cell monolayers. (A) F3II, (B) B16F0 cells. C, control; 0.5, 1, 10, 20 and $50 \mu \mathrm{M}$ concentrations of genistein.

migration are steps strongly involve in tumor progression, we studied the capacity of genistein $(10 \mathrm{mg} / \mathrm{kg} / \mathrm{day})$ to inhibit the generation of new blood vessels by tumor cell implants in vivo. Likewise, we evaluated the same effect with the administration of a soybean-based diet. Both treatments were able to reduce the number of blood vessels induced by tumor implants of F3II mammary carcinoma and B16F0 melanoma cells in syngeneic mice (Fig. 6). Treatments were not associated with over-toxic effects.

\section{Discussion}

The present studies provide evidence that daily in vivo administration of genistein reduced tumor-induced angiogenesis in syngeneic mice implanted with B16 or F3II cells. 
A

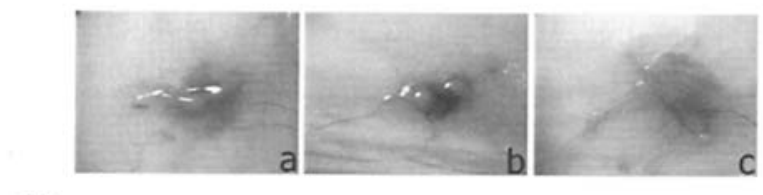

B

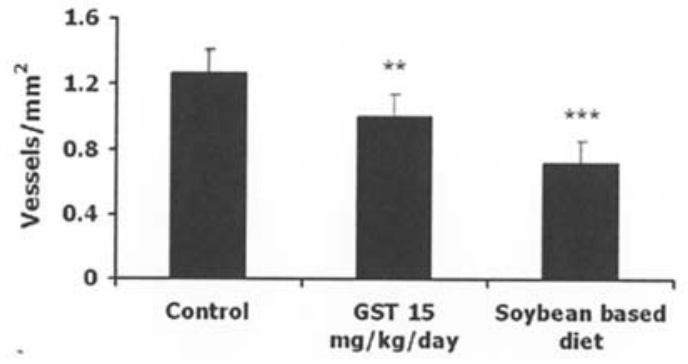

B16F0
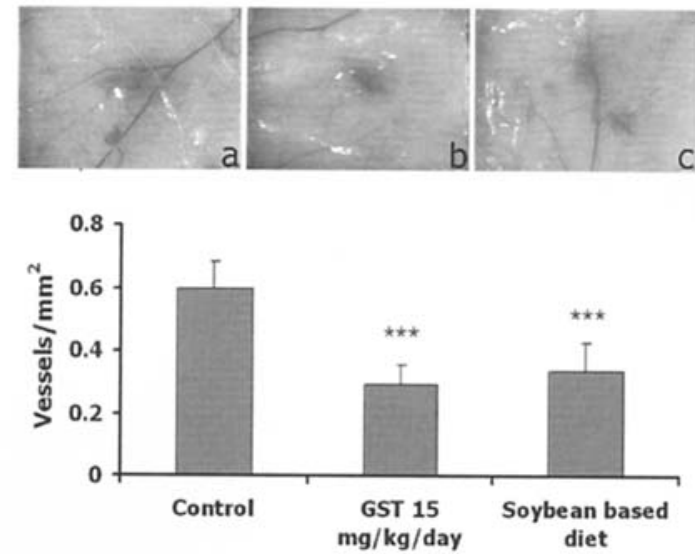

Figure 6. Effect of genistein on tumor-induced angiogenesis in vivo. Mice were injected i.p. with daily doses of genistein or received a soybean-based diet. (A) Representative images of data in B (a, control mice; b, genistein treatment; c, soybean-based diet). (B) Quantification of vessels around tumor implants, as described in Materials and methods. GST, genistein. Values represents means \pm SD of at least 8 determinations. ${ }^{* *}$ p $<0.01,{ }^{* * *} \mathrm{p}<0.001$ versus control $($ ANOVA test).

Similar antiangiogenic effects were obtained with a soybeanbased diet and are consistent with numerous other studies that have reported this inhibitory effect toward different tumor types (20). Our findings also provide additional experimental support suggesting that cell migration and proteolysis may be associated with the antitumor and antiangiogenic activity of genistein.

Genistein has been shown to inhibit the development of both hormone-related and non-hormone-related cancers, including mouse models of breast, prostate, and skin cancer. Several mechanisms have been proposed for this effect. Genistein and other isoflavones have demonstrated weak estrogenic activity at lower concentrations but are estrogen receptor antagonists at higher concentrations. At $40 \mu \mathrm{M}$, genistein inhibited proliferation of LNCaP prostate cancer cells and enhanced apoptosis. Treatment of human bladder cancer cells with genistein resulted in inhibition of cdc2 kinase activity and $\mathrm{G}_{2} / \mathrm{M}$ phase cell cycle arrest (21). Genistein has been shown to inhibit $20 \mathrm{~S}$ proteasomal activity in LNCaP and MCF7 cells, resulting in accumulation of p27 $7^{\mathrm{Kip}-1}$, ІкB and Bax (22). Genistein has also been shown to inhibit tyrosine kinase and topoisomerase activity (23). The relative importance of each of these mechanisms remains to be determined in vivo.

Previous reports also indicated that genistein exhibits strong antiangiogenic activity. The precise underlying mechanism of inhibition, however, remains unclear. We found that at non-cytotoxic concentrations genistein induced a dosedependent spindle-cell morphology in both cell lines. In parallel, we observed that F3II and B16 tumor cells exposed to genistein $(0.5-50 \mu \mathrm{M})$ increased the adhesion to coated or uncoated plastic surfaces. Bergan et al (24) carried out a morphogenic analysis revealing that genistein caused cell flattening in a variety of cell lines: PC3-M, PC3 and DU-145 prostate carcinoma cells, as well as MCF-7 breast carcinoma cells. Mechanistic studies focused on the highly metastatic PC3-M cell line, revealed that cell flattening was accompanied by an increase in cell adhesion. The authors suggest that binding of focal adhesion kinase to $ß 1$-integrin may be responsible for this biological behavior.

Proteolytic profiles were modified by genistein. In F3II cells genistein $(10-50 \mu \mathrm{M})$ decreased uPA and increased tPA. Interestingly, in B16 cells both uPA and tPA levels were increased. A decrease in uPA after genistein treatment was also reported by Valachovicova in breast cancer cells (25). The same results were found in prostatic cancer cells (26), in neuroblastoma cell lines (27) and endothelial cells (28). We report for the first time that genistein induced an increase in tPA, an enzyme related with good prognosis in mammary tumors, in both cell types. Furthermore, this is the first time where the effect of genistein on plasminogen activators is analyzed in a melanoma model.

No modification in the secretion pattern of metalloproteases was observed at non-cytotoxic doses tested. The same results were found by Sugiura et al in MDA-MB-231 (29). On the contrary, Kousidou et al showed that the addition of genistein resulted in down-regulation of the transcription of all MMP genes in MDA-MB-231 and most MMPs in MCF-7 cells (30).

Using an in vitro wound assay, we were able to assess the effects of genistein on tumor cell migration. Genistein significantly decreased F3II cell migration in doses ranging from 1 to $50 \mu \mathrm{M}$ for F3II, and from 20 to $50 \mu \mathrm{M}$ for B16 cells. Accordingly, Valachovicova et al demonstrated that genistein suppresses cell adhesion and migration by inhibiting the constitutively active transcription factors NF- $\mathrm{KB}$ and AP-1, resulting in the suppression of secretion of uPA in breast cancer cells MDA-MB-231 (25).

Cooperative functions of tumor invasion and tumor-induced angiogenesis were described during cell adhesion, proteolysis and cell migration (3). There are remarkable similarities in the molecular mechanism which enables tumor cells to invade into surrounding tissues and that which activates endothelial cells to generate new capillaries, which facilitate the growth and dissemination of cancer (31). In our experiments, both genistein and a soybean-based diet were able to reduce tumor- 
induced angiogenesis in breast and melanoma models in syngeneic mice. The same results using genistein in vivo were found by Wietrzyk et al in melanoma (11) and Shao et al in breast cancer (32). Among others, down-regulation of the vascular endothelium growth factor could be the main mechanism involved in the antiangiogenic effect of genistein (7). Hewitt and Singletary (8) showed an enhanced suppression of in vivo F3II cell invasiveness for animals fed a $0.6 \%$ soy extract-supplemented diet, suggesting that the inhibition of invasiveness by diets containing a mixture of soy constituents warrants further evaluation.

In addition, Connolly et al (33) demonstrated that dietary soy at $10 \%$ and $20 \%(\mathrm{w} / \mathrm{w})$ significantly reduced the lung invasiveness of MDA-MB-435 human breast cancer cells.

In 1991 Lee et al (34) reported that Asian women who consumed a traditional diet (high in soy products) had a low incidence of breast cancer. Yuan et al (35), however, reported no protection against breast cancer from soy consumption. In a third investigation, Wu et al (36) reported a correlation between tofu intake and a reduced rate of mammary cancer in a population-based case-control study of breast cancer among Chinese American, Japanese American, and Filipino American women.

There is a strong body of evidence relating soy consumption with a lower cancer incidence in humans. However, recent contrasting data have been reported on the potential of phytoestrogens to prevent hormone-dependent cancers (37). Our studies clearly demonstrated that tumor cell migration and proteolysis may be associated with the antitumor and antiangiogenic activity of soy isoflavone genistein. Its usefulness in humans should be studied carefully, and significant matters such as bioavailability and drug concentration should be clearly analyzed.

\section{Acknowledgements}

This study was supported by a Priority Research Grant Program (53/A048) from Quilmes National University, and by grants from Antorchas Foundation (4248-46) and the National Agency for Scientific and Technological Promotion (PICT 14256/03). D.E.G. and D.F.A. are Members of CONICET (Argentina).

\section{References}

1. Harlozinska A: Progress in molecular mechanisms of tumor metastasis and angiogenesis. Anticancer Res 25: 3327-3333, 2005.

2. Li CY, Shan S, Cao Y and Dewhirst MW: Role of incipient angiogenesis in cancer metastasis. Cancer Metastasis Rev 19: $7-11,2000$

3. Stetler-Stevenson WG and Corcoran ML: Tumor angiogenesis: functional similarities with tumor invasion. EXS 79: 413-418, 1997.

4. Thorgeirsson UP, Lindsay CK, Cottam DW and Gomez DE: Tumor invasion, proteolysis and angiogenesis. J Neurooncol 18: 89-103, 1994

5. Aguirre Ghiso JA, Alonso DF, Farias EF, Gomez DE and Bal de Kier Joffe E: Deregulation of the signaling pathways controlling urokinase production. Its relationship with the invasive phenotype. Eur J Biochem 263: 295-304, 1999.

6. Gomez DE, Alonso DF, Yoshiji H and Thorgeirsson UP: Tissue inhibitors of metalloproteinases; structure, regulation and biological functions. Eur J Cell Biol 74: 111-122, 1997.

7. Ravindranath $\mathrm{MH}$, Muthugounder S, Presser $\mathrm{N}$ and Viswanathan S: Anticancer therapeutic potential of soy isoflavone, genistein. Adv Exp Med Biol 546: 121-165, 2004.
8. Hewitt AM and Singletary KW: Soy extract inhibits mammary adenocarcinoma growth in a syngeneic mouse model. Cancer Lett 192: 133-143, 2003.

9. Kuzumaki T, Kobayashi $\mathrm{T}$ and Ishikawa K: Genistein induces p21(Cip1/WAF1) expression and blocks the G1 to S phase transition in mouse fibroblast and melanoma cells. Biochem Biophys Res Commun 251: 291-295, 1998.

10. Record IR, Broadbent JL, King RA, Dreosti IE, Head RJ and Tonkin AL: Genistein inhibits growth of B16 melanoma cells in vivo and in vitro and promotes differentiation in vitro. Int $\mathrm{J}$ Cancer 72: 860-864, 1997.

11. Wietrzyk J, Boratynski J, Grynkiewicz G, Ryczynski A, Radzikowski C and Opolski A: Antiangiogenic and antitumour effects in vivo of genistein applied alone or combined with cyclophosphamide. Anticancer Res 21: 3893-3896, 2001.

12. Menon LG, Kuttan R, Nair MG, Chang YC and Kuttan G: Effect of isoflavones genistein and daidzein in the inhibition of lung metastasis in mice induced by B16-F10 melanoma cells. Nutr Cancer 30: 74-77, 1998

13. Zhou JR, Mukherjee P, Gugger ET, Tanaka T, Blackburn GL and Clint SK: Inhibition of murine bladder tumorigenesis by soy isoflavones via alterations in the cell cycle, apoptosis and angiogenesis. Cancer Res 58: 5231-5238, 1998.

14. Alonso DF, Farías EF, Urtreger A, Ladeda V, Vidal MCC and Bal de Kier Joffé E: Characterization of F3II, a sarcomatoid mammary carcinoma cell line originated from a clonal subpopulation of a mouse adenocarcinoma. J Surg Oncol 62: 288-297, 1996.

15. Goodman SL, Vollmers HP and Birchmeir W: Control of the cell locomotion: Perturbation with an antibody directed against specific glycoproteins. Cell 41: 1029-1038, 1985.

16. Alonso DF, Farías EF, Ladeda V, Davel L, Puricelli L and Bal de Kier Joffé E: Effects of synthetic urokinase inhibitors on local invasion and metastatic dissemination in a murine mammary tumor model. Breast Cancer Res Treat 40: 209-233, 1996.

17. Saksela O: Radial caseinolysis in agarose: a simple method for detection of plasminogen activator in the presence of inhibitory substances and serum. Anal Biochem 111: 276-282, 1981.

18. Vassalli JD and Belin D: Amiloride selectively inhibits the urokinase-type plasminogen activator. FEBS Lett 214: 187-191, 1987.

19. De Lorenzo MS, Ripoll GV, Yoshiji H, Yamazaki M, Thorgeirsson UP, Alonso DF and Gomez DE: Altered tumor angiogenesis and metastasis of B16 melanoma in transgenic mice overexpressing tissue inhibitor of metalloproteinases-1. In vivo 17: 45-50, 2003

20. Su SJ, Yeh TM, Chuang WJ, Ho CL, Chang KL, Cheng HL, Liu HS, Cheng HL, Hsu PY and Chow NH: The novel targets for anti-angiogenesis of genistein on human cancer cells. Biochem Pharmacol 69: 307-318, 2005.

21. Su SJ, Yeh TM, Lei HY and Chow NH: The potential of soybean foods as a chemoprevention approach for human urinary tract cancer. Clin Cancer Res 6: 230-236, 2000.

22. Kazi A, Daniel KG, Smith DM, Kumar NB and Dou QP: Inhibition of the proteasome activity, a novel mechanism associated with the tumor cell apoptosis-inducing ability of genistein. Biochem Pharmacol 66: 965-976, 2003.

23. McCabe MJ Jr and Orrenius S: Genistein induces apoptosis in immature human thymocytes by inhibiting topoisomerase-II. Biochem Biophys Res Commun 194: 944-950, 1993.

24. Bergan R, Kyle E, Nguyen P, Trepel J, Ingui C and Neckers L: Genistein-stimulated adherence of prostate cancer cells is associated with the binding of focal adhesion kinase to beta-1integrin. Clin Exp Metastasis 14: 389-398, 1996.

25. Valachovicova T, Slivova V, Bergman, Shuherk J and Sliva D: Soy isoflavones suppress invasiveness of breast cancer cells by the inhibition of NF-kappaB/AP-1-dependent and -independent pathways. Int J Oncol 25: 1389-1395, 2004.

26. Skogseth H, Larsson E and Halgunset J: Inhibitors of tyrosine kinase inhibit the production of urokinase plasminogen activator in human prostatic cancer cells. APMIS 113: 332-339, 2005

27. Garcia de Veas R, Schweigerer L and Medina MA: Modulation of the proteolytic balance plasminogen activator/plasminogen activator inhibitor by enhanced $\mathrm{N}$-myc oncogene expression or application of genistein. Eur J Cancer 34: 1736-1740, 1998.

28. Kim MH: Flavonoids inhibit VEGF/bFGF-induced angiogenesis in vitro by inhibiting the matrix-degrading proteases. J Cell Biochem 89: 529-538, 2003. 
29. Sugiura T and Berditchevski F: Function of alpha3beta1tetraspanin protein complexes in tumor cell invasion. Evidence for the role of the complexes in production of matrix metalloproteinase 2 (MMP-2). J Cell Biol 146: 1375-1389, 1999.

30. Kousidou OC, Mitropoulou TN, Roussidis AE, Kletsas D, Theocharis AD and Karamanos NK: Genistein suppresses the invasive potential of human breast cancer cells through transcriptional regulation of metalloproteinases and their tissue inhibitors. Int J Oncol 26: 1101-1109, 2005.

31. Eccles S: Parallels in invasion and angiogenesis provide pivotal points for therapeutic intervention. Int J Dev Biol 48: 583-598, 2004.

32. Shao ZM, Wu J, Shen ZZ and Barsky SH: Genistein exerts multiple suppressive effects on human breast carcinoma cells. Cancer Res 58: 4851-4857, 1998.
33. Connolly JM, Liu XH and Rose DP: Effect of dietary menhaden oil, soy and a cyclooxygenase inhibitor on human breast cancer cell growth and metastasis in nude mice. Nutr Cancer 29: 48-54, 1997.

34. Lee HP, Gourley L, Duffy SW, Esteve J, Lee J and Day NE: Dietary effects on breast-cancer risk in Singapore. Lancet 337: 1197-1200, 1991.

35. Yuan JM, Wang QS, Ross RK, Henderson BE and Yu MC: Diet and breast cancer in Shanghai and Tianjin, China. Br J Cancer 71: 1353-1358, 1995.

36. Wu AH, Ziegler RG, Horn-Ross PL, Nomura AM, West DW, Kolonel LN, Rosenthal JF, Hoover RN and Pike MC: Tofu and risk of breast cancer in Asian-Americans. Cancer Epidemiol Biomarkers Prev 5: 901-906, 1996.

37. Sirtori CR, Arnoldi A and Johnson SK: Phytoestrogens: end of a tale? Ann Med 37: 423-438, 2005. 